\title{
Modulation of Pasteurella multocida capsular polysaccharide during growth under iron- restricted conditions and in vivo
}

\author{
M. Jacques, ${ }^{1}$ M. Bélanger, ${ }^{1}$ M. S. Diarra, ${ }^{2}$ M. Dargis ${ }^{2}$ and F. Malouin ${ }^{2}$ \\ Author for correspondence: M. Jacques. Tel: +1 5147738521 ext. 348. Fax: +1 5147735633.
}

1 Département de Pathologie et Microbiologie, Faculté de Médecine Vétérinaire, Université de Montréal, C.P. 5000 , St-Hyacinthe, Québec, Canada J2S 7C6

2 Laboratoire et Service d'Infectiologie, Centre de Recherche du Centre Hospitalier de I'Université Laval, Ste-Foy, Québec,

Canada G1V 4G2

\begin{abstract}
Addition of the iron chelators 2,2'-dipyridyl, deferoxamine mesylate or apotransferrin to culture media affected the composition and the morphology of Pasteurella multocida cells. Cells grown under iron-restricted conditions expressed iron-regulated proteins and, in addition, iron deprivation markedly reduced the amount of capsular material covering the cells of $P$. multocida. The addition of iron neutralized the effect of these chelators on capsule production. Cells of $\boldsymbol{P}$. multocida grown under iron-restricted conditions were more labelled by gold particles coated with polymyxin which is known to interact with the lipid A-core region of lipopolysaccharides, and showed increased affinity for porcine respiratory tract mucus than cells grown under iron-sufficient conditions. Bacterial cells grown in vivo in peritoneal chambers in rats were also only covered by a thin layer $(15-20 \mathrm{~nm})$ of capsular material. Although the capsule is believed to be an important virulence factor, our data indicate that under iron-restricted conditions, such as those encountered in vivo, $P$. multocida may not be heavily encapsulated.
\end{abstract}

Keywords: Pasteurella multocida, capsule, polysaccharide, iron restriction

\section{INTRODUCTION}

The environmental modulation of cell surface components of both Gram-positive and Gram-negative bacteria has been intensively investigated (Brown \& Williams, 1985). Among the environmental factors that commonly influence the properties of microbial cells, the availability of essential nutrients, such as iron, assumes particular importance. Studies on various bacterial species have shown that micro-organisms frequently adapt to conditions of iron restriction, as found in vivo, by undergoing a number of phenotypic changes including the induction of iron-regulated proteins (IRPs). Many Gram-negative bacteria synthesize high-affinity irontransport systems consisting of low-molecular-mass ironchelating agents (siderophores) and receptor proteins involved in the uptake and transport of the siderophoreiron complexes across both outer and cytoplasmic membranes (Brown \& Williams, 1985). In addition to the various alterations which occur in pathogenic bacteria during growth under iron restriction, the production of some classical virulence factors (e.g. certain bacterial

Abbreviations: DM, deferoxamine mesylate; DP, 2,2'-dipyridyl; IRP, ironregulated protein; OMP, outer-membrane protein. toxins or hydrolytic enzymes) is also affected (Griffiths \& Bullen, 1987; Mekalanos, 1992).

Little is known about the effect of iron deprivation on bacterial capsule production. In general, good polysaccharide synthesis is permitted in nutrient-limited growth media where nitrogen, sulfur or phosphate provide the limiting nutrient, and a utilizable carbon source is in excess (Sutherland, 1988). Metals have been shown to influence the production of capsule exopolymers but no generalizations can be made with respect to the effects that metals and other cations have on bacterial capsule production (Geesey \& Jang, 1989). Some researchers have found direct evidence that metal ions bind electrostatically with microbial polysaccharides, and various ions are known to be required as cofactors in polysaccharide synthesis (Geesey \& Jang, 1989; Sutherland, 1977). The biosynthesis of capsular polysaccharide by the bacterial cell is a complex process which begins with sugar activation in the cytoplasm. Following polymerization, catalysed by cytoplasmic membrane-bound transferases, the final stage is the translocation of polysaccharide to the cell surface (Jann \& Jann, 1990). Genes have been identified which are thought to encode products responsible for the translocation of the polysaccharides across the cytoplasmic and outer membranes, and the 
organization of exported polysaccharides into a capsule (Boulnois \& Jann, 1989).

Swine atrophic rhinitis is a multifactorial disease complex characterized by turbinate atrophy (Rutter, 1985). Pasteurella multocida, the etiological agent, possesses various putative virulence factors including a polysaccharide capsule, lipopolysaccharides (with endotoxic activities), and a dermonecrotic toxin (Chanter \& Rutter, 1989). In this study, we have examined the effects of growth under iron limitation on $P$. multocida production of capsular material, a potentially important virulence factor.

\section{METHODS}

Bacterial isolates and growth conditions. Three toxigenic isolates of $P$. multocida (2305-A and 23-4, capsular type A; 30-1, capsular type $D$ ), retrieved from the nasal cavities of pigs with atrophic rhinitis, were used in the present study. Bacterial isolates were grown on Mueller-Hinton agar plates, for $18 \mathrm{~h}$ at $37^{\circ} \mathrm{C}$ (iron-sufficient conditions). To obtain bacterial growth under conditions of iron restriction, organisms were inoculated onto plates supplemented with 2,2'-dipyridyl (DP; 60, 100 or $160 \mu \mathrm{M}$; Sigma), deferoxamine mesylate (DM; $50,100,150$ or $200 \mu \mathrm{M}$; Sigma), or with human or bovine apo-transferrin (1 $\mathrm{mg} \mathrm{ml}^{-1}$; Sigma).

Transmission electron microscopy. (i) Polycationic ferritin labelling. Bacterial cells were prepared for transmission electron microscopy following polycationic ferritin labelling, a method which allows good preservation of capsular material (Jacques \& Foiry, 1987; Jacques et al., 1990). Bacterial cells were fixed in cacodylate buffer $(0 \cdot 1 \mathrm{M}, \mathrm{pH} 7 \cdot 0)$ containing $5 \%(\mathrm{v} / \mathrm{v})$ glutaraldehyde, for $2 \mathrm{~h}$ at $20^{\circ} \mathrm{C}$. Fixed bacteria were suspended in cacodylate buffer and allowed to react with the polycationic ferritin, final concentration $1.0 \mathrm{mg} \mathrm{ml}^{-1}$, for $30 \mathrm{~min}$ at $20^{\circ} \mathrm{C}$ (Jacques \& Foiry, 1987). The reaction was slowed by 10 -fold dilution with buffer, and the organisms were centrifuged and washed three times in cacodylate buffer. Bacterial cells were then immobilized in $4 \%(\mathrm{w} / \mathrm{v})$ agar, washed five times in cacodylate buffer and post-fixed with $2 \%(\mathrm{w} / \mathrm{v})$ osmium tetroxide for $2 \mathrm{~h}$. Washings were repeated as above, and the samples dehydrated in a graded series of acetone washes. Samples were then washed twice in propylene oxide and embedded in Spurr low-viscosity resin. Thin sections were post-stained with uranyl acetate and lead citrate and examined with an electron microscope (Philips 201) at an accelerating voltage of $60 \mathrm{kV}$. The determination of capsular material thickness was based on 20-25 measurements (per preparation) on micrographs taken at a magnification of $45000 \times$. Since capsule is not always a uniform layer, the results are expressed as a range (in $\mathrm{nm}$ ).

(ii) Polymyxin B-gold labelling. The procedure used has been described by Morioka et al. (1987). Briefly, polymyxin B was conjugated with BSA using 1-ethyl-3-(3-dimethylaminopropryl) carbodiimide. Colloidal gold particles $(15 \mathrm{~nm})$ adjusted to $\mathrm{pH} 5.5$ were then coated with polymyxin B-BSA. Goldlabelled BSA was prepared as a control. A drop of a bacterial suspension was placed on a Formvar-coated electron microscope grid for $1 \mathrm{~min}$. Grids with bacteria were placed on drops of polymyxin B-BSA-gold for $30 \mathrm{~min}$. After washing, the grids were negatively stained with $0 \cdot 2 \%(\mathrm{w} / \mathrm{v})$ phosphotungstate and examined as mentioned above.

Protein profiles. Bacterial cells were harvested and whole cell protein profiles were analysed as described by Bélanger $e t$ al.
(1990). Briefly, bacteria were suspended in solubilization buffer containing $10 \%(\mathrm{v} / \mathrm{v})$ glycerol, $5 \%(\mathrm{v} / \mathrm{v}) \beta$-mercaptoethanol, $2 \%(\mathrm{w} / \mathrm{v}) \mathrm{SDS}, 0.0625 \mathrm{M}$ Tris $/ \mathrm{HCl}(\mathrm{pH} 6.8)$ and $0.025 \%(\mathrm{w} / \mathrm{v})$ bromophenol blue. Samples were heated for $15 \mathrm{~min}$ at $100^{\circ} \mathrm{C}$. Samples were separated by discontinuous SDS-PAGE using stacking gels of $4.5 \%(\mathrm{w} / \mathrm{v})$ polyacrylamide and separating gels of $12.5 \%(\mathrm{w} / \mathrm{v})$ polyacrylamide (Laemmli, 1970). Samples were electrophoresed at $100 \mathrm{~V}$ (stacking gel) and $200 \mathrm{~V}$ (separating gel), using a Mini-Protean II apparatus (Bio-Rad). Gels were stained with Coomassie brilliant blue R-250.

Outer-membrane protein (OMP) isolation. The method of Carlone et al. (1986) was followed for OMP isolation. Briefly, cells from $10 \mathrm{ml}$ of a culture adjusted to an $\mathrm{OD}_{600}$ of 0.5 were centrifuged and washed in $10 \mathrm{ml} 10 \mathrm{mM}$ HEPES (Sigma) buffer $(\mathrm{pH} \mathrm{7 \cdot 4)}$. The cells were centrifuged again and the cell pellet was frozen in liquid nitrogen. After suspension in $1 \mathrm{ml} \mathrm{HEPES}$ buffer, cells were sonicated three times for $1 \mathrm{~min}$ each time. Total membranes were collected by centrifugation at $16000 \mathrm{~g}$ for $30 \mathrm{~min}$ and suspended in $0 \cdot 2 \mathrm{ml}$ HEPES buffer. Inner membrane proteins were solubilized by the addition of an equal volume of $2 \%(\mathrm{w} / \mathrm{v}$ ) Sarkosyl ( $N$-lauroylsarcosamine; Sigma) in HEPES buffer for $30 \mathrm{~min}$; OMPs were recovered by centrifugation and the pellet was suspended in $30 \mu \mathrm{l}$ HEPES buffer. Samples were boiled for $5 \mathrm{~min}$ in solubilization buffer and separated by electrophoresis as described above.

Affinity for porcine respiratory tract mucus. To screen for mucus binding by $P$. multocida isolates, dot blots were performed (Bélanger et al., 1992). The trachea was removed from healthy adult pigs at the slaughter house, and crude mucus (containing approximately $1 \mathrm{mg}$ protein $\mathrm{ml}^{-1}$ ) was obtained following the procedure previously described by Letellier et al. (1991). A rabbit antiserum against the porcine crude respiratory tract mucus was prepared as described by Rozee et al. (1982). Ten microlitre samples of the bacterial suspensions were placed on a nitrocellulose membrane. All incubation steps were performed at room temperature, followed by four $3 \mathrm{~min}$ washes with a Tris-saline buffer (TSB; $10 \mathrm{mM}$ Tris, $150 \mathrm{mM} \mathrm{NaCl}, \mathrm{pH} 7 \cdot 4$ ). The membranes were first incubated for $1 \mathrm{~h}$ with $2 \%(\mathrm{w} / \mathrm{v})$ casein, a blocking solution, and for $1 \mathrm{~h}$ with the filtered mucus preparation diluted $1 / 5$. The membranes were then incubated for $2 \mathrm{~h}$ with a $1 / 50$ dilution of an antiserum against the mucus preparation followed by a $1 \mathrm{~h}$ incubation with a goat anti-rabbit IgG conjugated to peroxidase diluted 1/10000 (Bio-Rad). The reaction was revealed by addition of 4-chloro-1-naphthol and $\mathrm{H}_{2} \mathrm{O}_{2}$. Reference strain P. multocida 4-4056 (capsular type D) was used as a control with affinity for porcine respiratory tract mucus whereas Escherichia coli $\mathrm{O} 111$ was used as a negative control.

Diffusion chambers and in vivo growth conditions. We have examined cells of isolates 23-4 and 2305-A grown in diffusion chambers implanted in the peritoneal cavity of rat for $18 \mathrm{~h}$ as described by Malouin et al. (1990). Diffusion chambers $(15 \times 10 \mathrm{~mm})$ were constructed from polypropylene tubing (Nalgene). Millipore MF $0.22 \mu \mathrm{m}$ filters were cut to the diameter of the barrels and attached by melting the chambers to affix the filter. The chambers were autoclaved. Overnight cultures of bacteria diluted to $10^{8}$ c.f.u. $\mathrm{ml}^{-1}$ in saline were injected through a needle hole melted through the side of the barrels. The hole was subsequently closed using a hot glass rod. Chamber volume was approximately $500 \mu \mathrm{l}$. Sprague Dawley female rats, approximately $250 \mathrm{~g}$, were anaesthetized i.p. with Ketamine $\mathrm{HCl}$ $\left(87 \mathrm{mg} \mathrm{kg}^{-1}\right)$ and xylazine $\left(13 \mathrm{mg} \mathrm{kg}^{-1}\right)$. Four chambers were placed in the peritoneal cavity through a small longitudinal incision in the abdomen. Animals were sacrificed using carbon dioxide before chambers were removed. 

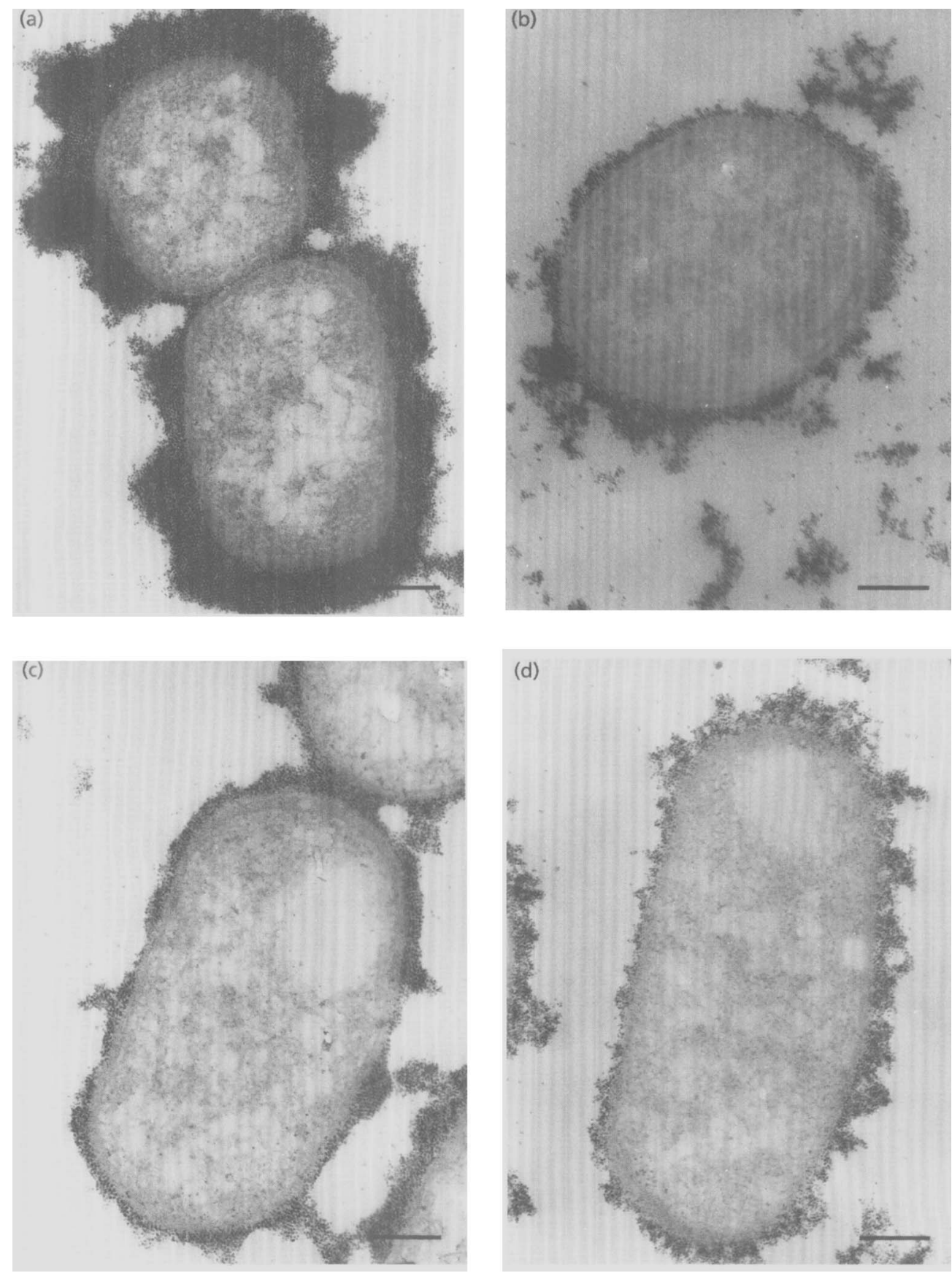

Fig. 1. Transmission electron micrographs of thin sections of cells of $P$. multocida isolate 2305-A labelled with polycationic ferritin. Cells were grown in vitro under iron-sufficient conditions (a) or iron-restricted conditions obtained after the addition of $160 \mu \mathrm{M} \mathrm{DP}$ (b), $150 \mu \mathrm{M} \mathrm{DM}$ (c), or $1 \mathrm{mg}$ bovine apo-transferrin $\mathrm{ml}^{-1}$ (d). Bars, $200 \mathrm{~nm}$.

\section{RESULTS and DISCUSSION}

Cells of $P$. multocida grown under iron-sufficient conditions were covered with a dense layer of ferritin granules of approximately 55-65 nm for the isolates 30-1 and 23-4, and of $105-125 \mathrm{~nm}$ for the isolate $2305-\mathrm{A}$, whereas cells grown under iron-restricted conditions were covered with a much thinner layer of 15-30 nm (Fig. 1). Growth of these isolates in the presence of increasing concentrations of an iron chelator, either DP or DM, resulted in a marked reduction in capsular material thickness (Fig. 2a).

To support the idea that the presence of a thinner capsular 


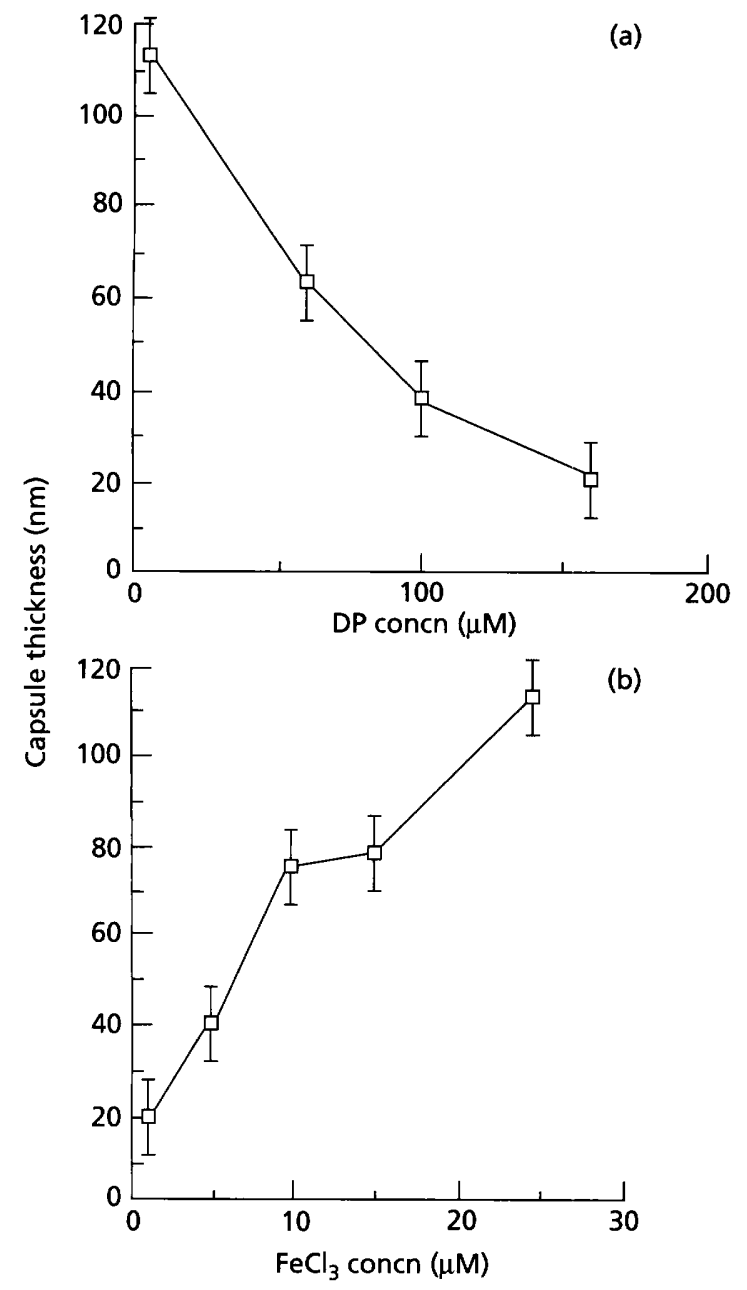

Fig. 2. (a) Effects of various concentrations of DP on capsule thickness of $P$. multocida isolate 2305-A. (b) Effects of the addition of $\mathrm{FeCl}_{3}$ on capsule thickness of $P$. multocida isolate 2305-A grown on media containing $160 \mu \mathrm{M} \mathrm{DP}$

material was due to growth under iron-restricted conditions, we first added different concentrations of $\mathrm{FeCl}_{3}$ to media containing $160 \mu \mathrm{M}$ DP (Fig. 2b) or $200 \mu \mathrm{M}$ DM. Repletion of iron restored completely the capsular material production of all isolates to the level seen with cells grown under iron-sufficient conditions. It is noteworthy that growth of $P$. multocida isolates in the presence of an excess of iron (Mueller-Hinton agat plates supplemented with 10 or $25 \mu \mathrm{M} \mathrm{FeCl}_{3}$ ) had no effect on their capsular material production.

It has been shown that avian and bovine isolates of $P$. multocida grown under iron-restricted conditions produced a siderophore termed multocidin (Hu et al., 1986) and also expressed several IRPs of molecular masses ranging from 76 to $96 \mathrm{kDa}$ (Choi-Kim et al., 1991; Ikeda \& Hirsh, 1988; Ogunnariwo et al., 1991; Snipes et al., 1988). Iron-restricted conditions were also confirmed by determining the protein profiles of $P$. multocida grown

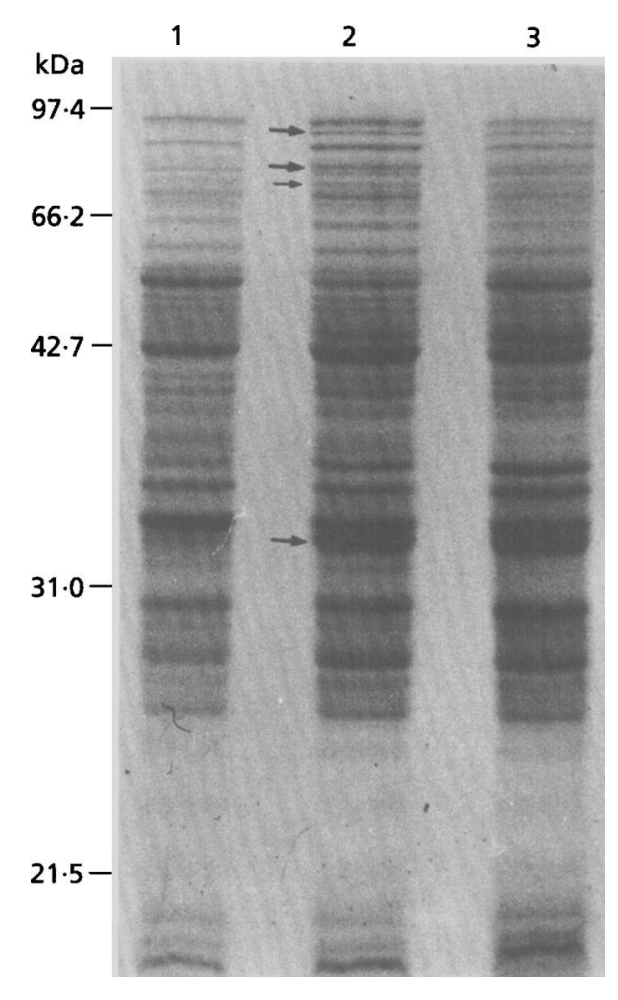

Fig. 3. Comparison of SDS-PAGE profiles of proteins, stained with Coomassie brilliant blue, from $P$. multocida 2305-A grown under iron-sufficient (lane 1), or iron-restricted conditions obtained after the addition of $160 \mu \mathrm{M}$ DP (lane 2) or $200 \mu \mathrm{M}$ DM (lane 3). Arrows denote the presence of ironregulated proteins. Molecular mass markers are indicated on the left.

under iron-restricted and iron-sufficient conditions. Bacterial cells were harvested and whole cell protein profiles were analysed by SDS-PAGE. The results showed that IRPs were expressed by our porcine isolates grown in iron-restricted media. For example, IRPs of molecular masses of $80,75,72$ and $33.5 \mathrm{kDa}$ were observed for $P$. multocida 2305-A isolate (Fig. 3, arrows).

Cells grown under iron-restricted conditions were resuspended in fresh iron-sufficient liquid medium (Mueller-Hinton broth). We observed that as soon as after $30 \mathrm{~min}$ of incubation in fresh iron-sufficient medium, the production of capsular material had increased; after $1-2 \mathrm{~h}$ of incubation the cells were well capsulated and similar in appearance to control cells grown overnight under iron-sufficient conditions.

We used polymyxin B-gold labelling to visualize the accessibility of lipopolysaccharides (LPS) at the surface of cells grown under iron-sufficient or iron-restricted conditions. Cells grown under iron-sufficient conditions were weakly labelled (Fig. 4a) whereas cells grown under ironrestricted conditions were heavily labelled by the polymyxin B-BSA-gold particles (Fig. 4b). No labelling was 

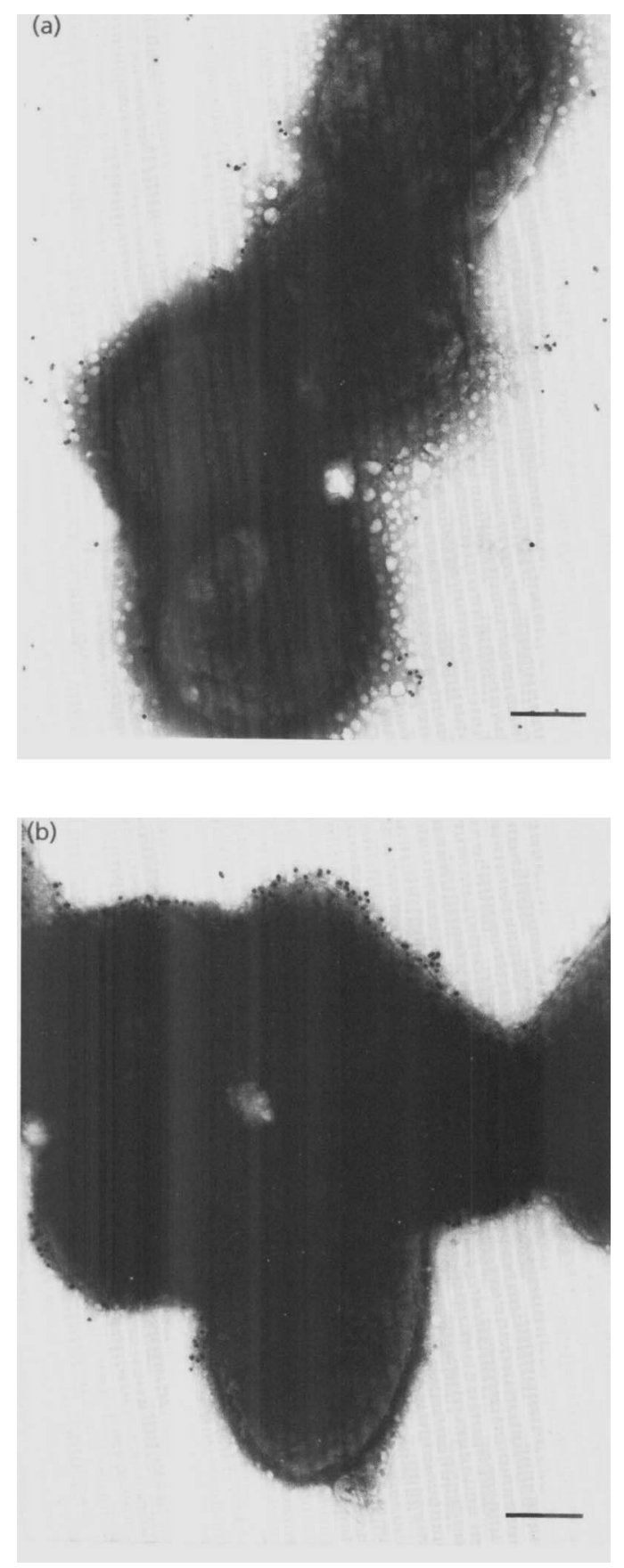

Fig. 4. Transmission electron micrographs of cells of $P$. multocida isolate 23-4 grown under iron-sufficent (a) or ironrestricted conditions (b) and labelled with polymyxin B-BSAgold particles $(15 \mathrm{~nm})$. Bars, $200 \mathrm{~nm}$.

observed when BSA-gold particles were used. Results obtained using polymyxin B, a substance known to interact with the lipid A-core region of LPS molecules (Morioka et al., 1987), indicate that LPS is, as anticipated, more accessible at the surface of cells grown under iron-

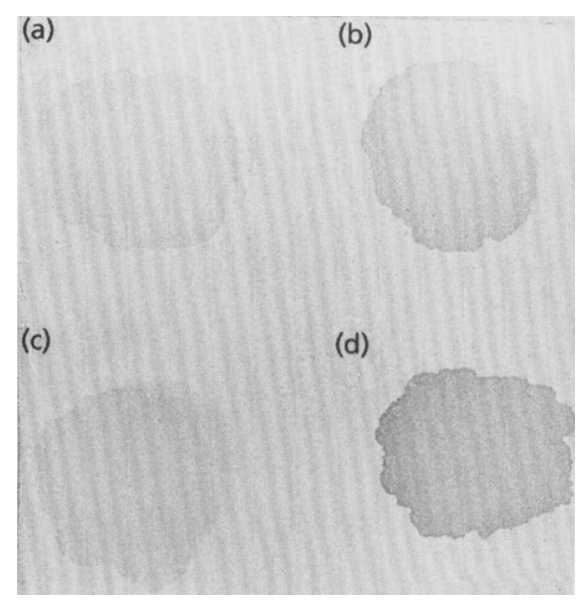

Fig. 5. Dot blot assay used to show binding of porcine respiratory tract mucus to isolates of $P$. multocida. Bacterial cells, immobilized on the membrane, were sequentially incubated with a mucus preparation and an antiserum against the mucus preparation. $P$. multocida 2305-A grown under ironsufficient (a) or iron-restricted (b) conditions. P. multocida 23-4 grown under iron-sufficient (c) or iron-restricted (d) conditions.

restricted conditions and which are covered by a thinner layer of capsular material.

Because we have previously found that the LPS of Actinobacillus pleuropneumoniae, another important swinepathogenic member of the Pasteurellaceae, was important for adherence to host cells and mucus (Bélanger et al., 1990, 1992), we suspected that a thinner layer of capsular material could help adherence of $P$. multocida. We then used dot blotting on a nitroceliulose membrane to evaluate the binding of porcine respiratory tract mucus to $P$. multocida isolates. Bacterial cells were immobilized on the membrane and sequentially incubated with the mucus preparation and an antiserum against the mucus preparation. Bacteria grown under iron-restricted conditions on dipyridyl-containing medium showed increased adherence to porcine respiratory tract mucus (Fig. 5). Bacteria grown under iron-restricted conditions also showed increased adherence to porcine frozen lung and trachea sections (data not shown). These results suggest that the thicker capsular material layer of $P$. multocida grown under iron-sufficient conditions masks outermembrane components which are involved in adherence.

Finally, we have examined cells of isolates 23-4 and 2305A grown in diffusion chambers implanted in the peritoneal cavity of rats for $18 \mathrm{~h}$. The growth of $P$. multocida was monitored after implantation of diffusion chambers; the number of viable cells initially inoculated $\left(3 \times 10^{8}\right.$ c.f.u. $\left.\mathrm{ml}^{-1}\right)$ increased a little more than three times (to $10^{9}$ c.f.u. $\mathrm{ml}^{-1}$ ) after $18 \mathrm{~h}$ incubation. Cells of $P$. multocida 23-4 grown in vivo were covered with a layer of capsular material much thinner $(15-20 \mathrm{~nm})$ than the one observed on cells grown in vitro under iron-sufficient conditions (Fig. 6); similar results were obtained with the 

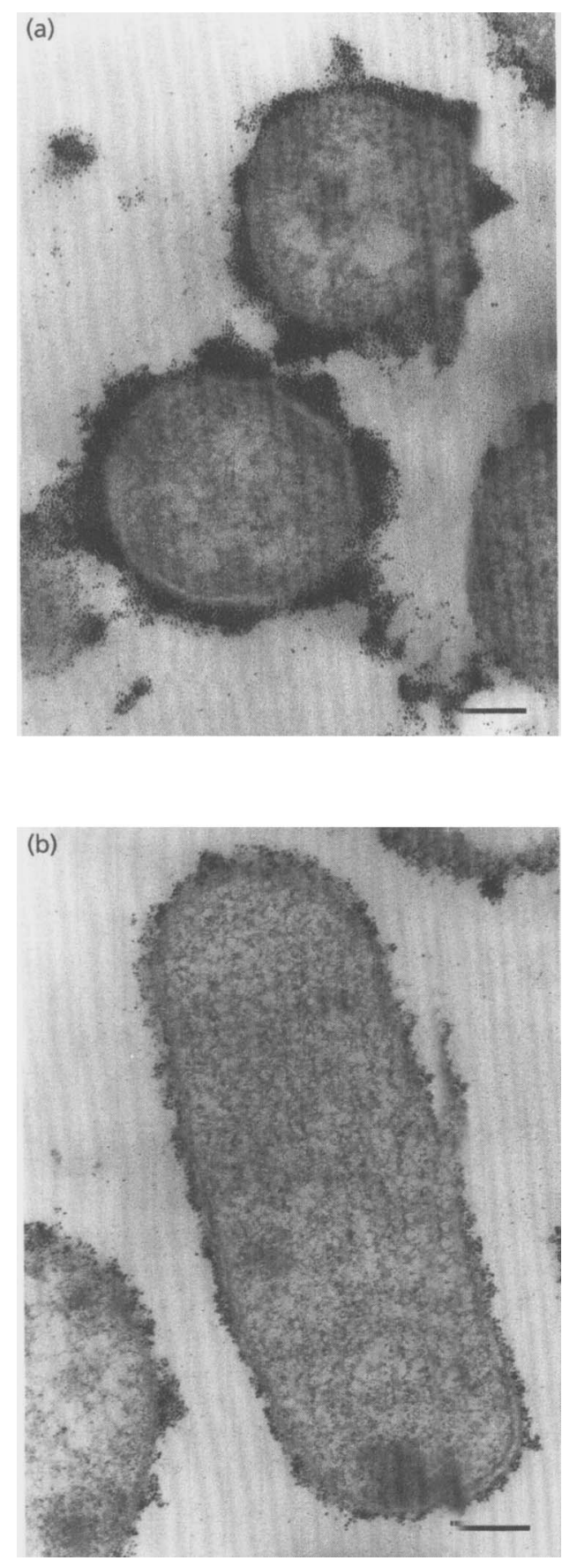

Fig. 6. Transmission electron micrographs of thin sections of cells of $P$. multocida isolate 23-4 labelled with polycationic ferritin. Cells were grown in vitro under iron-sufficient conditions (a) or in vivo in rat peritoneal diffusion chambers (b). Bars, $200 \mathrm{~nm}$.

P. multocida 2305-A isolate. These reductions in capsular material thickness were not due to growth in liquid because $P$. multocida cells were well capsulated after cultivation in Mueller-Hinton broth. Rather, changes observed in chamber grown cells may be due to iron

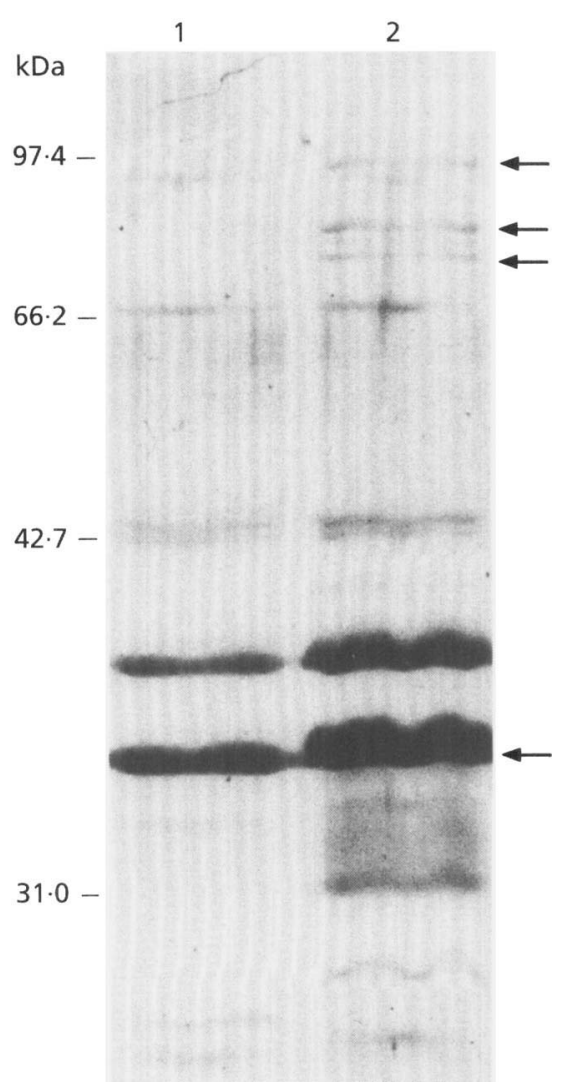

Fig. 7. Comparison of SDS-PAGE profiles of OMPs, stained with Coomassie brilliant blue, from $P$. multocida 2305-A grown under iron-sufficient conditions (lane 1 ) and prior to cultivation in vivo, or after a $16 \mathrm{~h}$ growth period in diffusion chambers in rats (lane 2). Arrows denote the presence of some proteins induced by in vivo growth and similar in molecular mass to some of the iron-regulated proteins indicted in Fig. 3. Molecular mass markers are indicated on the left.

deprivation. Indeed, growth in diffusion chambers resulted in the expression of proteins similar to those induced by iron-restricted conditions in vitro (Fig. 3) and seemed to be mainly located on the outer membrane of cells (Fig. 7). However, at this point we still cannot exclude that factors other than iron limitation may be involved in the modulation of expression of capsular material in vivo.

To our knowledge, few studies have looked at the effects of iron limitation on bacterial ultrastructure. Large periplasmic spaces have been observed in Haemophilus ducreyi grown under iron limitation (Abeck et al., 1990). Ferrala et al. (1986) observed that under iron starvation, the capsule of Azotobacter cbroococcum appeared more diffuse and extensive, and speculated that it might serve to enhance iron sequestration. Iron limitation, an environmental condition relevant to the lungs of patients with cystic fibrosis, was shown to result in conversion of Pseudomonas aeruginosa to the mucoid phenotype (Terry et al., 1992). Here, nutrient (iron) limitation seemed to have an opposite effect on $P$. multocida capsule production. 
There is also a possibility that iron limitation leads to greater release or looser attachment of exopolysaccharides.

Bacterial pathogens have evolved highly sophisticated environmental signal transduction systems, and the expression of virulence factors is frequently coordinately controlled by a common regulatory system (Mekalanos, 1992). The capsular material regulation in $P$. multocida may be part of a response to iron-restricted growth conditions that includes derepression of genes for the synthesis of an iron-acquisition system. It is also possible that iron acts as a cofactor in the biosynthesis of $P$. multocida capsular polysaccharides.

In vivo, where free iron concentration is extremely low, the reduction in capsule formation by $P$. multocida might result in a better exposure on the bacterial cell surface of its adhesin(s) which could be advantageous for this microorganism. Our results clearly showed that adherence of $P$. multocida to porcine respiratory tract mucus, and to lung and trachea sections was enhanced for bacteria having a thinner capsular material, a morphological change induced by iron restriction in vitro or by growth in animals. We have previously shown that LPS molecules may be important adhesins for $A$. pleuropneumoniae (Bélanger $e t$ al., $1990,1992)$ and have shown here that the lipid A-core region of LPS in P. multocida was more accessible when cells presented less capsular material. A thinner layer of capsular material in $P$. multocida correlated with a greater adherence but more work is needed to show the importance of LPS for attachment to host cells. Thus, although capsule is believed to be an important virulence factor, $P$. multocida may not be heavily encapsulated when growing under iron-limited conditions.

\section{ACKNOWLEDGEMENTS}

This work was supported by a grant from Natural Sciences and Engineering Research Council of Canada (A3428) to M. J. We thank Martine Caya, Annie Lebrun, Stéphane Rioux, and Bernadette Foiry for technical assistance. M. Bélanger is the recipient of a Studentship, and F. Malouin, the recipient of a Scholarship from the Medical Research Council of Canada.

\section{REFERENCES}

Abeck, D., Johnson, A. P., Korting, H. C., Stolz, W., Struck-Sauer, E. \& Braun-Falco, O. (1990). Effect of iron limitation on protein composition and ultrastructure of Haemophilus ducreyi. FEMS Microbiol Lett 68, 41- 44.

Bélanger, M., Dubreuil, D., Harel, J., Girard, C. \& Jacques, M. (1990). Role of lipopolysaccharides in adherence of Actinobacillus pleuropneumoniae to porcine tracheal rings. Infect Immun 58, 3523-3530.

Bélanger, M., Rioux, S., Foiry, B. \& Jacques, M. (1992). Affinity for porcine respiratory tract mucus is found in some isolates of Actinobacillus pleuropneumoniae. FEMS Microbiol Lett 97, 119126.

Boulnois, G. J. \& Jann, K. (1989). Bacterial polysaccharide capsule synthesis, export and evolution of structural diversity. Mol Microbiol 3, 1819-1823.

Brown, M. R. W. \& Williams, P. (1985). The influence of en- vironment on envelope properties affecting survival of bacteria in infections. Annu Rev Microbiol 39, 527-556.

Carlone, G. M., Thomas, M. L., Rumschlag, H. S. \& Sottnek, F. O. (1986). Rapid microprocedure for isolating detergent-insoluble outer membrane proteins from Haemophilus influenzae. J Clin Microbiol 24, 330-332.

Chanter, N. \& Rutter, J. M. (1989). Pasteurellosis in pigs and the determinants of virulence of toxigenic Pasteurella multocida. In Pasteurella and Pasteurellosis, pp. 161-195. Edited by C. Adlam \& J. M. Rutter. London: Academic Press.

Choi-Kim, K., Maheswaran, S. K., Felice, L. J. \& Molitor, T. W. (1991). Relationship between the iron regulated outer membrane proteins and the outer membrane proteins of in vivo grown Pasteurella multocida. Vet Microbiol 28, 75-92.

Ferrala, N. F., Champlin, A. K. \& Fekete, F. A. (1986). Morphological differences in the capsular polysaccharide of nitrogenfixing Azotobacter cbroococcum B-8 as a function of iron and molybdenum starvation. FEMS Microbiol Lett 33, 137-142.

Geesey, G. G. \& Jang, L. (1989). Interactions between metal ions and capsular polymers. In Metal Ions and Bacteria, pp. 325-357. Edited by T. J. Beveridge \& R. J. Doyle. New York: John Wiley \& Sons.

Griffiths, E. \& Bullen, J. J. (1987). Iron and infection: future prospects. In Iron and Infection, pp. 283-317. Edited by J. J. Bullen \& E. Griffiths. New York: John Wiley \& Sons.

Hu, S.-P., Felice, L. J., Sivanandan, V. \& Maheswaran, S. K. (1986). Siderophore production by Pasteurella multocida. Infect Immun 54, 804-810.

Ikeda, J. S. \& Hirsh, D. C. (1988). Antigenically related ironregulated outer membrane proteins produced by different somatic serotypes of Pasteurella multocida. Infect Immun 56, 2499-2502.

Jacques, M. \& Foiry, B. (1987). Electron microscopic visualization of capsular material of Pasteurella multocida types A and D labeled with polycationic ferritin. J Bacteriol 169, 3470-3472.

Jacques, M., Gottschalk, M., Foiry, B. \& Higgins, R. (1990). Ultrastructural study of surface components of Streptococcus suis. $J$ Bacteriol 172, 2833-2838.

Jann, B. \& Jann, K. (1990). Structure and biosynthesis of the capsular antigens of Eschericbia coli. Curr Top Microbiol Immunol 150, $19-42$.

Laemmli, U. K. (1970). Cleavage of structural proteins during the assembly of the head of bacteriophage T4. Nature 227, 680-685.

Letellier, A., Dubreuil, D., Roy, G., Fairbrother, J. M. \& Jacques, M. (1991). Determination of affinity of Pasteurella multocida isolates for porcine respiratory tract mucus, and partial characterization of the receptors. Am J Vet Res 52, 34-39.

Malouin, F., Campbell, G. D., Halpenny, M., Becker, G. W. \& Parr, T. R., Jr (1990). Outer membrane and porin characteristics of Serratia marcescens grown in vitro and in rat intraperitoneal diffusion chambers. Infect Immun 58, 1247-1253.

Mekalanos, J. J. (1992). Environmental signals controlling expression of virulence determinants in bacteria. J Bacteriol 174, 1-7.

Morioka, H., Tachibana, M., Machino, M. \& Suganuma, A. (1987). Polymyxin B binding sites in Escherichia coli as revealed by polymyxin B-gold labeling. J Histocbem Cytochem 35, 229-231.

Ogunnariwo, J.A., Alcantara, J. \& Schryvers, A. B. (1991). Evidence for non-siderophore-mediated acquisition of transferrinbound iron by Pasteurella multocida. Microb Pathog 11, 47-56.

Rozee, K. R., Cooper, D., Lam, K. \& Costerton, J. W. (1982). Microbial flora of the mouse ileum mucous layer and epithelial surface. Appl Environ Microbiol 43, 1451-1463. 
Rutter, J. M. (1985). Atrophic rhinitis in swine. Adv Vet Sci Comp Med 29, 239-279.

Snipes, K. P., Hansen, L. M. \& Hirsh, D. C. (1988). Plasma- and ironregulated expression of high molecular weight outer membrane proteins by Pasteurella multocida. Am J Vet Res 49, 1336-1338.

Sutherland, I. W. (1977). Bacterial exopolysaccharides - their nature and production. In Surface Carbobydrates of the Prokaryotic Cell, pp. 27-96. Edited by I. W. Sutherland. London: Academic Press.
Sutherland, I. W. (1988). Bacterial surface polysaccharides: structure and function. Int Rev Cytol 113, 187-231.

Terry, J. M., Pina, S. E. \& Mattingly, S. S. (1992). Role of energy metabolism in conversion of nonmucoid Pseudomonas aeruginosa to the mucoid phenotype. Infect Immun 60, 1329-1335.

Received 2 July 1993; accepted 9 September 1993. 